\title{
Evaluation of the impact of high pressure on the storage of filled traditional chocolates
}

\author{
João Dias $^{\mathrm{a}, \mathrm{b}, *}$, Patrícia Coelho ${ }^{\mathrm{a}}$, Nuno B. Alvarenga ${ }^{\mathrm{a}, \mathrm{b}, \mathrm{c}}$, Ricardo V. Duarte ${ }^{\mathrm{d}}$, Jorge A. Saraiva ${ }^{\mathrm{d}}$ \\ a Polytechnic Institute of Beja, Rua Pedro Soares, 7800-295 Beja, Portugal \\ b LEAF, Instituto Superior de Agronomia, Universidade de Lisboa, Tapada da Ajuda, 1349-017 Lisbon, Portugal \\ c GeoBioTec Research Institute, Universidade Nova de Lisboa. Campus da Caparica, 2829-516 Caparica, Portugal \\ d QOPNA, Department of Chemistry, University of Aveiro, 3810-193 Aveiro, Portugal
}

\begin{abstract}
A B S T R A C T
The aim of this study was to evaluate the influence of high hydrostatic pressure (HHP) (400 MPa for 2.5 min and $500 \mathrm{MPa}$ for $1 \mathrm{~min}$ ) and storage temperature $\left(4^{\circ} \mathrm{C}\right.$ and $\left.20^{\circ} \mathrm{C}\right)$, on the physicochemical, rheological and microbiological properties of filled chocolates during storage time. The results showed that the physicochemical (moisture, water activity and $\mathrm{pH}$ ) and microbiological parameters (total aerobic mesophiles, moulds and yeasts) were particularly affected, at $20{ }^{\circ} \mathrm{C}$, during storage time $(\mathrm{P}<0.05)$. The dynamic rheological parameters $\left(\mathrm{G}^{\prime}\right.$ and $\mathrm{G}^{\prime \prime}$ ) were not affected by pressure or time of HHP treatment, but were affected by the higher storage temperature especially after $180 \mathrm{~d}$. The mechanical spectra of chocolate fillings stored at $4{ }^{\circ} \mathrm{C}$ was the least affected, when compared with the chocolates stored at $20^{\circ} \mathrm{C}\left(0.1 \mathrm{MPa} / 20^{\circ} \mathrm{C}, 400 \mathrm{MPa} / 20^{\circ} \mathrm{C}\right.$ and $500 \mathrm{MPa} /$ $20^{\circ} \mathrm{C}$ ).

Industrial relevance: The preservation of traditional filled chocolates can present some hurdles due to the use of perishable raw materials, physical changes during processing, and also to the influence of external factors, which tend to shorten shelf-life. The most important factors that contribute to the shelf-life of filled chocolates include physical properties (i.e. drying, sugar bloom or fat bloom), microbiological stability (i.e. the use of ingredients with high water content will ease the development of moulds and yeasts) and chemical properties (i.e. oxidation of fatty acids or hydrolysis of fatty acids or saponification). The use of HHP in filled chocolates could be an important contribution to improve the food safety of high quality filled chocolates as an alternative to conventional heating treatments or refrigeration.
\end{abstract}

\section{Introduction}

Preservation of traditional chocolate fillings can present some difficulties due to the use of perishable raw materials, physical changes during processing and also to the influence of external factors. These factors will shorten shelf-life of traditional formulations, even following the highest quality standards during processing and storage (Wybauw, 2010). Shelf-life has been defined in various ways, but a useful definition is given by the Institute of Food Science and Technology as "the period of time when the product remains safe, is certain to retain desired sensory, chemical, physical and microbiological characteristics, and complies with any label declaration of nutritional data" (IFST, 1993). Product factors such as composition, raw material quality, product structure, moisture content, water activity (Aw), fat content, liquid fat content, $\mathrm{pH}$ and sensitivity to oxygen are all important intrinsic factors affecting shelf life (Subramaniam, 2009). Reported changes that limit shelf life of filled chocolates are related with colour changes due to fat bloom (Ali, Selamat, Che Man, \& Suria, 2001; Beckett, 2008; Briones \& Aguilera, 2005; Dahlenborg, MillqvistFureby, \& Bergenståh, 2015; Jinap, Ali, Che Man, \& Suria, 2000), browning reactions (Vercet, 2003), moisture/fat migration (Beckett, 2008; Dahlenborg et al., 2015; Svanberg, Lorén, \& Ahrné, 2012) or changes in flavor (Ali et al., 2001; Popov-Raljić \& Laličić-Petronijević, 2009). Despite this, spoilage of chocolate fillings can be mainly due to the growth of microorganisms tolerating low water activity, like osmophilic yeasts, xerophilic fungi (De Clercq et al., 2015), and bacteria that tolerate low Aw, causing off-flavors, slime formation (Marvig, Kristiansen, Madsen, \& Nielsen, 2014), gas production that leads to cracking of the chocolates, sour fillings or visible fungus formation between filling and chocolate shell (Wybauw, 2010).

The long term solutions for a higher shelf-life include the reduction of $\mathrm{Aw}$ or $\mathrm{pH}$, and the use of ethanol or preservatives (Marvig et al.,

\footnotetext{
* Corresponding author at: Polytechnic Institute of Beja, Rua Pedro Soares, 7800-295 Beja, Portugal.

E-mail address: joao.dias@ipbeja.pt (J. Dias).
} 
2014; Wybauw, 2010). However, most of ganache recipes contain a considerable amount of water from the ingredients (Curley, 2011; Dias, Alvarenga, \& Sousa, 2015; Wybauw, 2004), e.g. fruit purée or cream, which is the responsible for the pleasant, creamy smooth and light structure of filled chocolate (Wybauw, 2010), and an excessive reduction in its content could compromise the organoleptic acceptance of the product. Moreover, the consumer demand for clean label products is on the rise, and alcohol addition in confections is not allowed in some countries (De Clercq et al., 2015).

In high hydrostatic pressure (HHP) treatment, the packaged food is placed in the pressure vessel and submitted to water pressures from 100 to $600 \mathrm{MPa}$. The pressure applied is isostatically transmitted (Pascal's law and Le Chatellier principle) to the inside of the pressure vessel; the food is compressed independently of the product size and geometry because transmission of pressure to the core is not mass/time dependent and thus the processing time is minimized (Aymerich, Picouet, \& Monfort, 2008). During the last decade, the use of HHP for food processing preservation has increased substantially. Foods commercially processed by HHP are subjected to pressures around 400-600 MPa to destroy microorganisms and inactivate enzymes (Santos et al., 2016). Generally, Gram-negative and cells in the growth phase are more sensitive than Gram-positive and cells in stationary phase. On the other hand, effective destruction of microbial spores often needs a treatment over $1000 \mathrm{MPa}$. Eukaryote vegetative forms from fungi and moulds are inactivated with pressures of 200-300 MPa while their spores need a $400 \mathrm{MPa}$ treatment (Aymerich et al., 2008). HHP treatment is also considered a non-thermal process as the adiabatic heating is only about $3{ }^{\circ} \mathrm{C}$ per $100 \mathrm{MPa}$ (Aymerich et al., 2008). The application of HHP in food industry has covered different areas including pre-treatment of frozen mackerel (Vázquez, Torres, Gallardo, Saraiva, \& Aubourg, 2013), production of probiotic yogurt (Mota, Lopes, Delgadillo, \& Saraiva, 2015; Penna, SubbaraoGurram, \& Barbosa-Cánovas, 2007), red wine (Santos et al., 2016), apple puree (Landl, Abadias, Sárraga, Viñas, \& Picouet, 2010), preservation of red sweet pepper (Hernández-Carrión, Hernando, SoteloDíaz, Quintanilla-Carvajal, \& Quiles, 2015), minimally processed peach pieces (Denoya et al., 2016), juices (Aganovic et al., 2017), dried apples (Janowicz \& Lenart, 2015), dry-cured ham (Clariana et al., 2011), sausages (Diez, Santos, Jaime, \& Rovira, 2008), and olives (Pradas et al., 2012). However, no studies have yet been reported in chocolate industry.

Taking all in consideration, the aim of this study was so to compare the use of HHP treatments with refrigeration as a preservation method to extend the shelf-life of filled pralines produced according to the traditional handmade process.

\section{Materials and methods}

\subsection{Preparation}

Filled chocolates were produced in a local confectionery (Sugar Bloom, Beja, Portugal), using tempered dark chocolate 51\% cocoa for couverture (CHD-R515-565, Sicao) and chocolate filling ("ganache") using white chocolate (CDW-U2630-557, Sicao) and cream (33\% fat) in a 2:1 proportion. The preparation of chocolate filling started with heating up the cream to $90^{\circ} \mathrm{C}$, using a heating plate with a magnetic stirrer. After reaching $90{ }^{\circ} \mathrm{C}$, white chocolate was added using a two blades hand blender to homogenize the mixture (Multiquick 5MR500, Braun, Aschaffenburg, Germany). The mixture was allowed to cool down to $30{ }^{\circ} \mathrm{C}$ at room temperature. Then, approximately $6 \mathrm{~g}$ of filling were piped manually into the previously prepared dark chocolate cavities (30 mm size $\times 26 \mathrm{~mm}$ height) using a piping bag. After demolding, the filled chocolates (pralines) were kept at $25^{\circ} \mathrm{C}$ for $24 \mathrm{~h}$, to fully crystallize the cocoa butter, and packed in flexible polyethylene bags (five pralines per bag) (PA/PE-90, Albipack-Packaging Solutions, Águeda, Portugal) and vacuum sealed (Vacuum packager Packman,
Albipack—Packaging Solutions).

\subsection{High hydrostatic pressure treatments}

HHP treatments were carried out in a 55-L high pressure equipment (Hiperbaric 55, Hiperbaric, Burgos, Spain) at $400 \mathrm{MPa} / 2.5 \mathrm{~min}$ and $500 \mathrm{MPa} / 1 \mathrm{~min}$. This HHP equipment has a pressure vessel of $200 \mathrm{~mm}$ inner diameter and $2000 \mathrm{~mm}$ length and a maximum operation pressure of $600 \mathrm{MPa}$, connected to a refrigeration unit (RMA KH $40 \mathrm{LT}$, Ferroli, San Bonifacio, Italy) for temperature control of the inlet water used as the pressurizing fluid. Pressure build-up took place at a compression rate of approximately $200 \mathrm{MPa} / \mathrm{min}$ and adiabatic heating caused an increase in temperature of, approximately, $3{ }^{\circ} \mathrm{C}$ for each $100 \mathrm{MPa}$ applied, while the decompression occurred instantaneously.

\subsection{Storage conditions}

After pressurization, the bags were stored at $20^{\circ} \mathrm{C}$. Additionally, two other batches of filled pralines were produced following the procedure referred above, vacuum packed in the same polyethylene bags, and stored at $4{ }^{\circ} \mathrm{C}$ and $20^{\circ} \mathrm{C}$ under atmospheric pressure ( $\left.0.1 \mathrm{MPa}\right)$, but were not submitted to HHP treatment. All filled chocolates were stored for 6 months and analyses were performed every month.

\subsection{Physical and chemical analyses}

Moisture content was determined using the gravimetric method 931.04 of the Official Methods of Analysis (AOAC, 1990). The Aw values were measured, at $20 \pm 1{ }^{\circ} \mathrm{C}$, using a Rotronic Hygropalm HP23-A water activity meter (Bassersdorf, Switzerland), using the electric hygrometer principle. The $\mathrm{pH}$ was evaluated at $20 \pm 1{ }^{\circ} \mathrm{C}$ using a Metrohm 691 pH Meter (Herisau, Switzerland). All analyses were conducted in quintuplicate.

The colour of the fillings and chocolate couverture was evaluated using a Minolta CR300 colorimeter (Tokyo, Japan), with $8 \mathrm{~mm}$ diameter measuring area, diffuse illumination by pulsed xenon arc lamp and $0 \%$ standard illuminate. Calibration was made using a Minolta CR-A43 white calibration plate $(\mathrm{Y}=92.7 \mathrm{x}=0.3134, \mathrm{y}=0.3195)$. Absolute measurements were taken in quintuplicate and recorded as CIE $1976 \mathrm{~L}^{*} \mathrm{a} * \mathrm{~b} *$ colour system. The parameter $\mathrm{L}^{*}$ is the lightness variable and ranges from 0 (black) to 100 (white), the chromaticity coordinate $\mathrm{a}^{*}$ ranges from green (negative) to red (positive), the chromaticity coordinate $b^{*}$ ranges from blue (negative) to yellow (positive). Whiteness index (WI) was calculated using the following equation (Nopens et al., 2008):

$\mathrm{WI}=100-\left[(100-\mathrm{L})^{2}+\mathrm{a}^{2}+\mathrm{b}^{2}\right]^{0.5}$

Small amplitude oscillatory measurements of chocolate fillings were performed using a controlled shear-strain rheometer (Kinexus lab +, Malvern, England) connected to a refrigeration circuit with controlled temperature. The viscoelastic behaviour of the fillings was evaluated at $20^{\circ} \mathrm{C}$ using a $4^{\circ} / 40 \mathrm{~mm}$ cone and plate geometry and gap distance of $1 \mathrm{~mm}$. First, excess sample was trimmed with a thin plastic blade and the sample was allowed to rest for $5 \mathrm{~min}$ for temperature equilibrium. Later, the linear viscoelastic region (LVR) was evaluated by performing a strain sweep $(0.001 \%-1000 \%)$ at a steady frequency of $1 \mathrm{~Hz}$. Finally, the dynamic frequency sweep was conducted applying a steady strain of $0.01 \%$, within the LVR, from $0.01 \mathrm{~Hz}$ to $100 \mathrm{~Hz}$. The rheological parameters for this study were the storage $\left(G^{\prime}\right.$, in Pa) and loss $\left(G^{\prime \prime}\right.$, in $\mathrm{Pa}$ ) moduli. All analyses were conducted in triplicate.

\subsection{Microbiological analysis}

Samples of filled chocolate (12 g) were diluted (1:10, in volume) in Ringer solution BR0052G (Oxoid, Hampshire, UK) and homogenized for $1 \mathrm{~min}$ in a Stomacher 400 Circulator (Seward, UK). A $1.0 \mathrm{~mL}$ aliquot 
of the homogenate was serially 10 -fold diluted and $0.1 \mathrm{~mL}$ aliquots of appropriate dilutions were spread onto duplicate plates. The media for total aerobic mesophiles viable organisms was Plate Count Agar CM0325 (Oxoid, Hampshire, UK), incubated at $30{ }^{\circ} \mathrm{C}$ for $72 \mathrm{~h}$. The media for moulds and yeasts was Rose-Bengal Chloramphenicol Agar Base CM0549 (Oxoid, Hampshire, UK), incubated at $25^{\circ} \mathrm{C}$ for $120 \mathrm{~h}$. Microbiological analyses were conducted in duplicate.

\subsection{Statistical analysis}

The average, standard deviation and $95 \%$ confidence interval values were determined. For statistical analysis, experimental data were subjected to one-way ANOVA (pairwise comparison of means with Scheffé test), Pearson's correlation coefficients ( $r$ ) were calculated between evaluated parameters and the storage time using the level of significance $\mathrm{P}<0.05$. All statistical analyses were carried out with the software Statistica 6.0 (StatSoft Inc., USA).

\section{Results}

\subsection{Chemical parameters}

The initial moisture value of chocolate filling was $25 \% \mathrm{w} / \mathrm{w}$ (Fig. 1), higher than other traditional formulations (Dias, Almeida, Adikevičius, Andzevičius, \& Alvarenga, 2016; Wybauw, 2010) as a consequence of the higher cream content used in the formulation adopted in the present study, but still lower than reduced-fat chocolate fillings (Dias et al., 2015). During storage time, all tested conditions presented a significant decrease of moisture content, especially at $20^{\circ} \mathrm{C}(\mathrm{P}<0.05)$, and samples submitted to HHP treatment presented a steeper moisture depletion during the early $120 \mathrm{~d}$ storage. After $180 \mathrm{~d}$ storage, pralines submitted to HHP treatment $400 \mathrm{MPa} / 20{ }^{\circ} \mathrm{C}$ presented the lowest content $(16.6 \% \mathrm{w} / \mathrm{w})$, followed by HHP treatment $500 \mathrm{MPa} / 20^{\circ} \mathrm{C}(17.9 \%$ $\mathrm{w} / \mathrm{w})$ and $0.1 \mathrm{MPa} / 20^{\circ} \mathrm{C}(18.3 \% \mathrm{w} / \mathrm{w})$, but no significant differences were observed $(\mathrm{P}>0.05)$.

The initial values of Aw were, approximately, 0.85 (Fig. 2), similar to the results obtained by other authors (Miquelim, Alcantara, \& Lannes, 2011), and decreased during storage time to final values between $0.68\left(500 \mathrm{MPa} / 20^{\circ} \mathrm{C}\right)$ and $0.71\left(0.1 \mathrm{MPa} / 4{ }^{\circ} \mathrm{C}\right)$. According to previous studies, high Aw affects the swelling capacity of chocolate, especially when 0.8 is reached, resulting in a rapid swelling by interaction and absorption of water by the particulate solids (Svanberg et al., 2012), which can result in the cracking of the coating

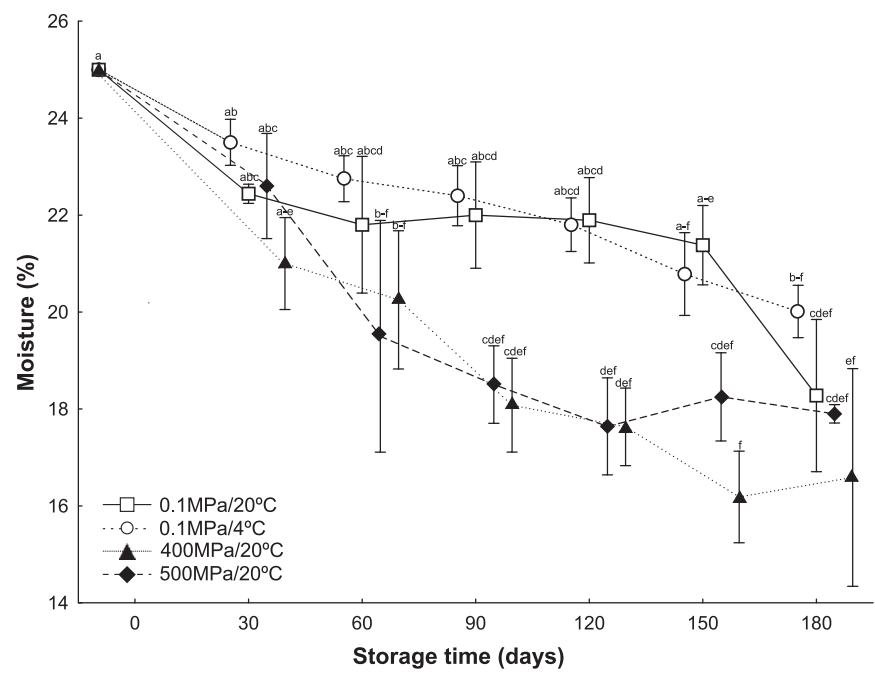

Fig. 1. Moisture during storage time (means of five replicates). Different letters (a-f) indicate significant differences $(P<0.05$, Scheffé test). Vertical error bars represent the standard deviation.

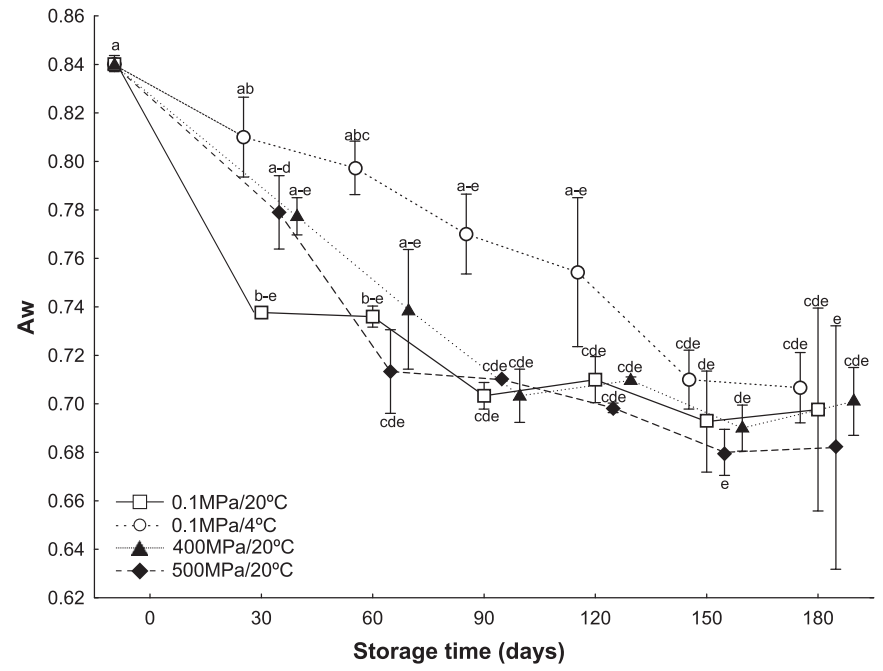

Fig. 2. Aw during storage time (means of five replicates). Different letters (a-e) indicate significant differences $(\mathrm{P}<0.05$, Scheffé test). Vertical error bars represent the standard deviation.

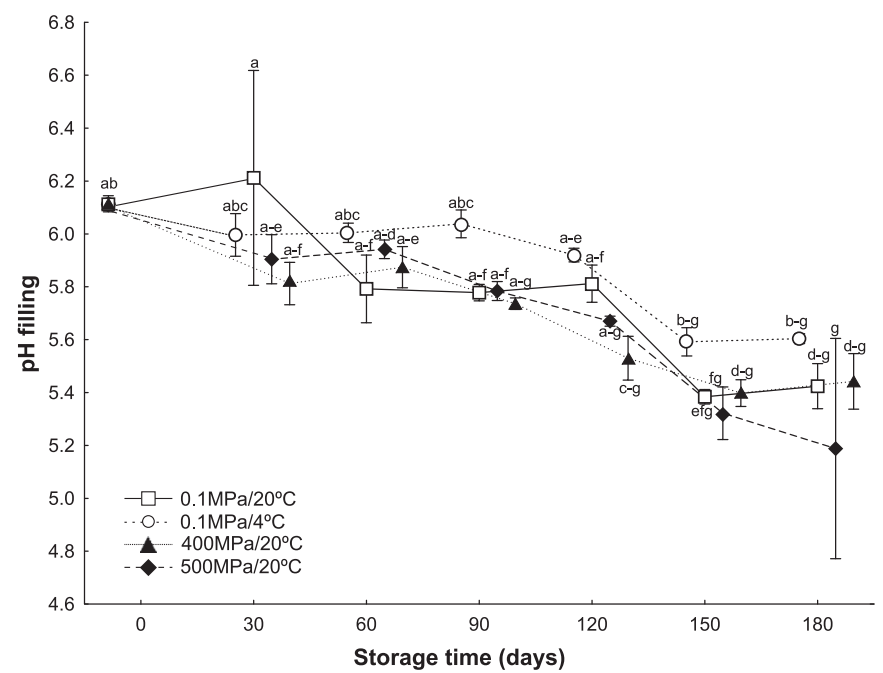

Fig. 3. $\mathrm{pH}$ during storage time (means of five replicates). Different letters (a-g) indicate significant differences $(\mathrm{P}<0.05$, Scheffé test). Vertical error bars represent the standard deviation.

(Ghosh, Ziegler, \& Anantheswaran, 2002). The presence of cracks further enhances the rate of migration, which can be the cause for the moisture loss until $180 \mathrm{~d}$, observed in all samples (Fig. 1).

The initial $\mathrm{pH}$ value was 6.1 (Fig. 3), which is in agreement with data in the literature (Dias et al., 2015) and decreased during storage time to values between $5.2\left(500 \mathrm{MPa} / 20^{\circ} \mathrm{C}\right)$ and $5.6\left(0.1 \mathrm{MPa} / 4^{\circ} \mathrm{C}\right)$ after $180 \mathrm{~d}$ storage time. These results are supported by the negative Pearson's correlation coefficients $(\mathrm{P}<0.05)$ between moisture, Aw, $\mathrm{pH}$ and storage time (Table 1 ).

\subsection{Colour}

The whiteness index (WI) of chocolate couverture presented an initial value approximately 34.06 , similar to the results obtained in other studies for chocolate (Briones \& Aguilera, 2005; Briones, Aguilera, \& Brown, 2006; Nightingale, Lee, \& Engeseth, 2011; PopovRaljić \& Laličić-Petronijević, 2009). During storage time, WI increased to values between $45.27\left(400 \mathrm{MPa} / 20^{\circ} \mathrm{C}\right)$ and $45.89\left(500 \mathrm{MPa} / 20^{\circ} \mathrm{C}\right)$ after $180 \mathrm{~d}$ (Fig. 4), consequence of fat bloom development (Beckett, 2008). No significant differences were observed on WI of couverture 
Table 1

Pearson's correlation coefficients $(r)$ with storage time $(n=6)$.

\begin{tabular}{lllll}
\hline Parameters & \multicolumn{3}{l}{$\mathrm{HHP} /$ storage temperature } \\
\cline { 2 - 5 } & $0.1 \mathrm{MPa} / 4^{\circ} \mathrm{C}$ & $\begin{array}{l}0.1 \mathrm{MPa} / \\
20^{\circ} \mathrm{C}\end{array}$ & $\begin{array}{l}400 \mathrm{MPa} / \\
20^{\circ} \mathrm{C}\end{array}$ & $\begin{array}{l}500 \mathrm{MPa} / \\
2{ }^{\circ} \mathrm{C}\end{array}$ \\
\hline Moisture & $-0.95^{*}$ & $-0.64^{*}$ & $-0.85^{*}$ & $-0.79^{*}$ \\
Aw & $-0.94^{*}$ & $-0.77^{*}$ & $-0.86^{*}$ & $-0.85^{*}$ \\
WI couverture & $0.92^{*}$ & $0.87^{*}$ & $0.88^{*}$ & $0.96^{*}$ \\
pH filling & $-0.82^{*}$ & $-0.79^{*}$ & $-0.91^{*}$ & $-0.92^{*}$ \\
WI filling & $-0.78^{*}$ & $-0.81^{*}$ & $-0.82^{*}$ & $-0.82^{*}$ \\
$\mathrm{G}^{\prime}(1 \mathrm{~Hz})$ & $0.75^{*}$ & $0.77^{*}$ & $0.87^{*}$ & $0.82^{*}$ \\
Total mesophiles & $-0.78^{*}$ & $-0.40^{*}$ & -0.26 & -0.16 \\
$\quad\left(30^{\circ} \mathrm{C}\right)$ & & & & \\
Moulds and yeasts & $0.71^{*}$ & $0.46^{*}$ & $0.66^{*}$ & $0.68^{*}$
\end{tabular}

(*) Marked correlations are significant at $\mathrm{P}<0.05$.

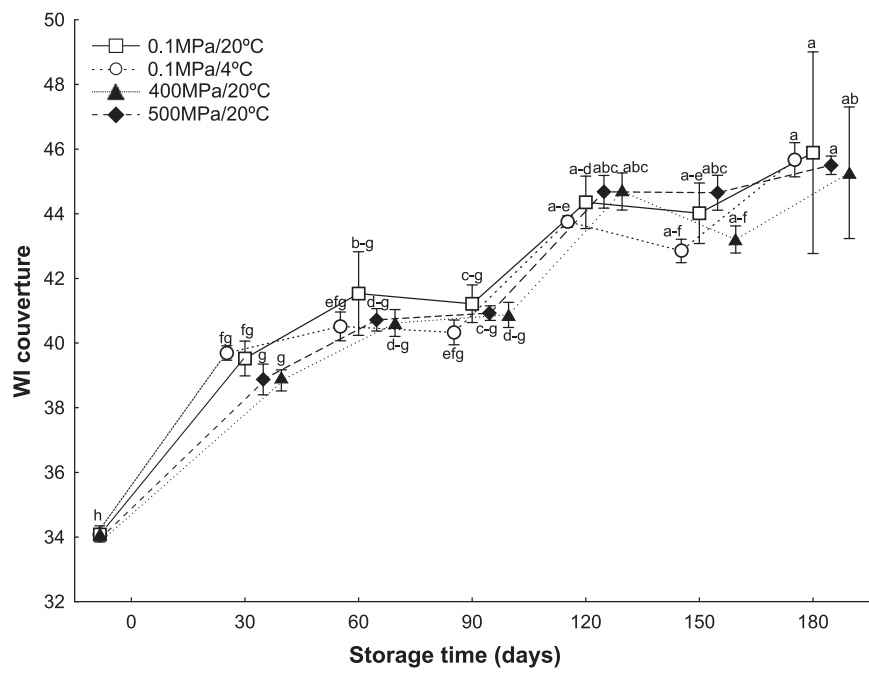

Fig. 4. Whiteness index of chocolate couverture during storage time (means of five replicates). Different letters $(\mathrm{a}-\mathrm{h})$ indicate significant differences $(\mathrm{P}<0.05$, Scheffé test). Vertical error bars represent the standard deviation.

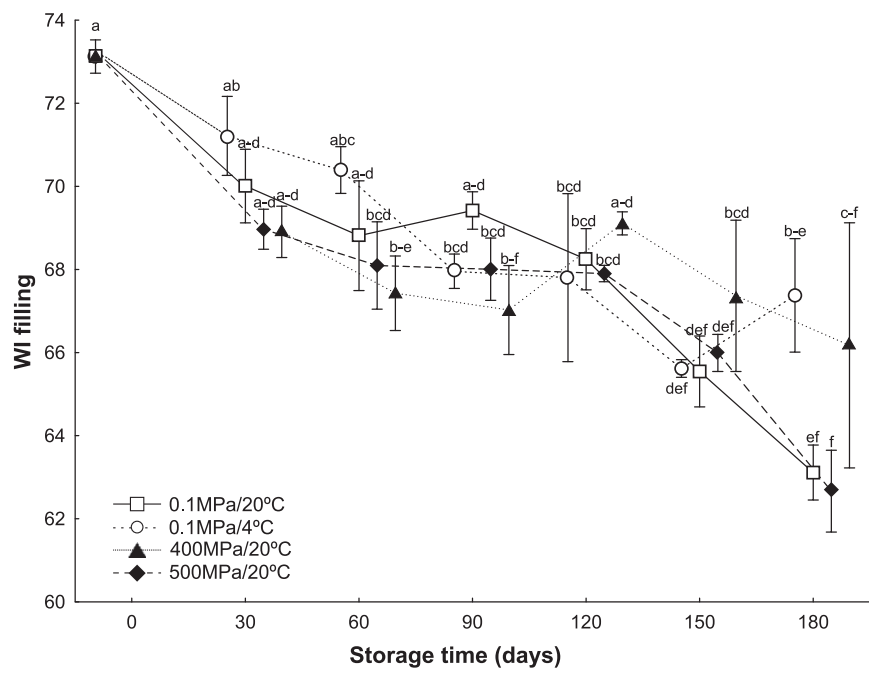

Fig. 5. Whiteness index of chocolate filling during storage time (means of five replicates). Different letters $(\mathrm{a}-\mathrm{f})$ indicate significant differences $(\mathrm{P}<0.05$, Scheffé test). Vertical error bars represent the standard deviation.

chocolate between the HHP and non-HHP batches during storage time $(\mathrm{P}>0.05)$. On the other hand, the WI of the filling presented initial values similar to other studies on white chocolate fillings with virgin

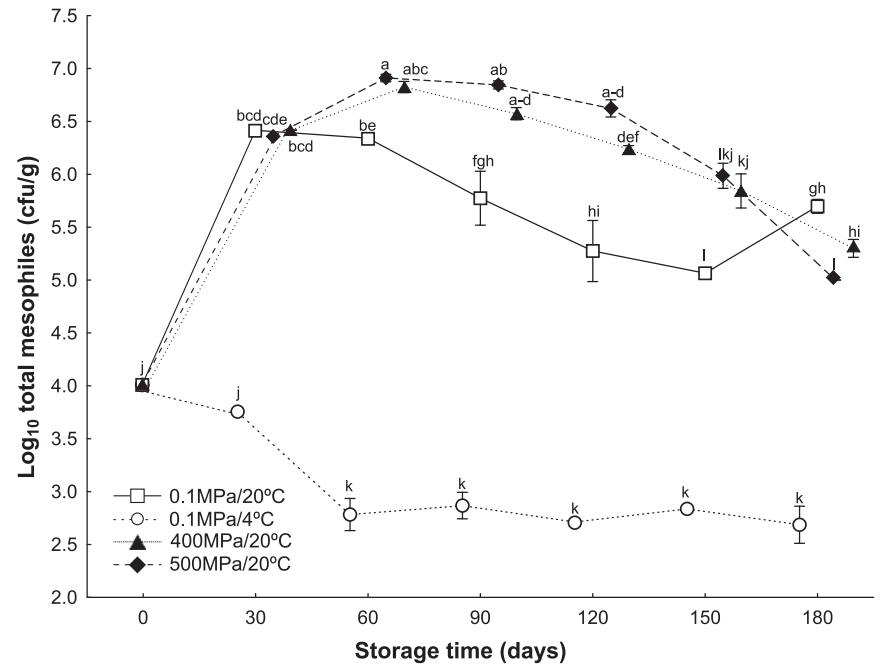

Fig. 6. Total mesophiles $\left(\log _{10} \mathrm{cfu} / \mathrm{g}\right)$ during storage time (means of two replicates) Different letters $(\mathrm{a}-\mathrm{k})$ indicate significant differences $(\mathrm{P}<0.05$, Scheffé test). Vertical error bars represent the standard deviation.

olive oil, approximately 73.12 (Dias et al., 2016). During storage time, WI of filling decreased to values between $62.67\left(500 \mathrm{MPa} / 20^{\circ} \mathrm{C}\right)$ and $67.38\left(0.1 \mathrm{MPa} / 4^{\circ} \mathrm{C}\right)$, after $180 \mathrm{~d}$ storage time, consequence of the diffusion of cocoa solids from chocolate couverture to the white chocolate filling (Fig. 5).

The lower values observed at $500 \mathrm{MPa} / 20^{\circ} \mathrm{C}$ may result from micelle disintegration induced by HHP treatment, causing a shift from the typical white colour into yellowish (Chawla, Patil, \& Singh, 2011). These two different evolutions are confirmed by Pearson's correlation coefficients (Table 1 ).

\subsection{Microbiological parameters}

The initial microbial load of pralines was $4.06 \log _{10} \mathrm{cfu} / \mathrm{g}$ for total aerobic mesophiles (Fig. 6) and $1.78 \log _{10} \mathrm{cfu} / \mathrm{g}$ for moulds and yeasts (Fig. 7), values similar to previous studies using pralines with fat-based fillings (Marvig et al., 2014). This initial load may be due to a possible chocolate contamination (Marvig et al., 2014) or due to the chocolate factory environment (De Clercq et al., 2015). Previous studies on different types of pralines (Marvig et al., 2014) concluded that

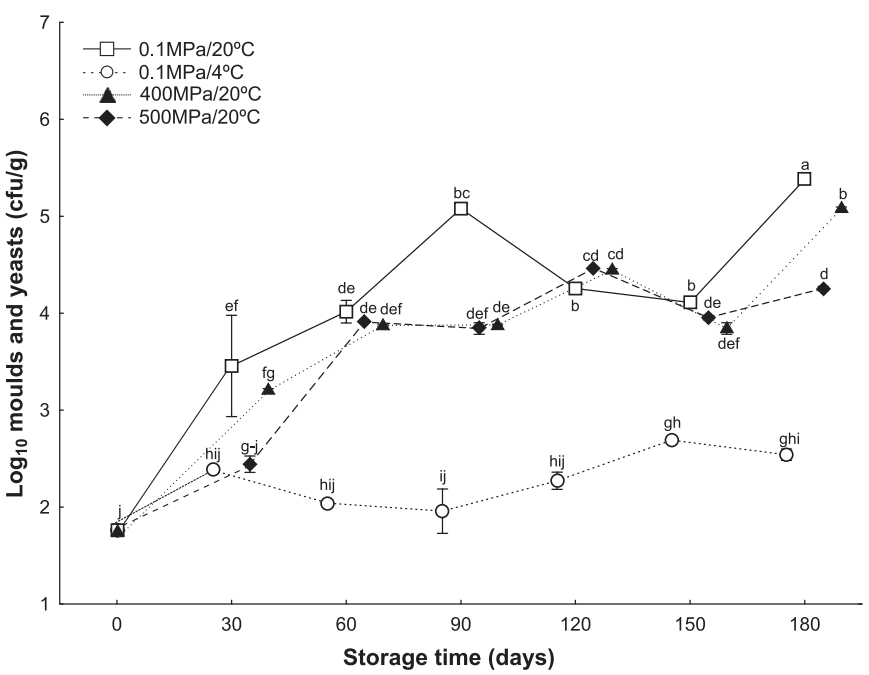

Fig. 7. Moulds and yeasts $\left(\log _{10} \mathrm{cfu} / \mathrm{g}\right)$ during storage time (means of two replicates). Different letters $(a-j)$ indicate significant differences $(P<0.05$, Scheffé test). Vertical error bars represent the standard deviation. 


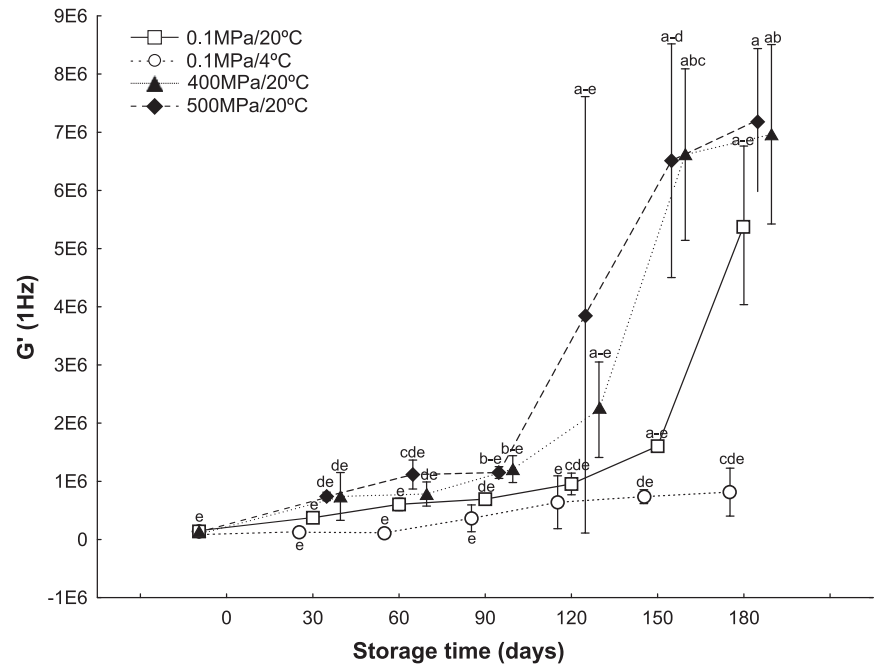

Fig. 8. $\mathrm{G}^{\prime}(1 \mathrm{~Hz})$ during storage time (means of two replicates). Different letters (a-e) indicate significant differences $(\mathrm{P}<0.05$, Scheffé test). Vertical error bars represent the standard deviation.

contaminations were dominated by yeasts (mainly Zygosaccharomyces rouxii), followed by moulds (mainly Penincillium spp. and Aspergillus spp.) and bacteria (mainly Bacillus spp. and Staphylococcus spp.). During storage, an evolution was observed in the microbiological flora type, since in the earlier stages, contamination by moulds and yeasts

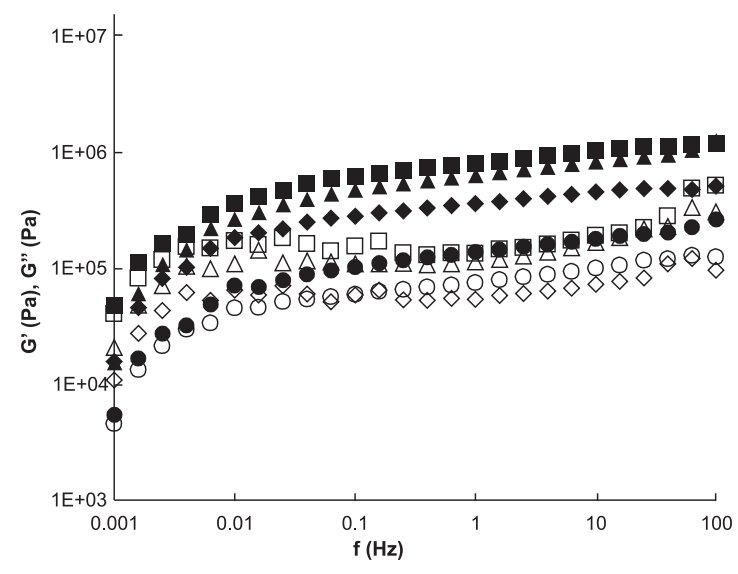

$0.1 \mathrm{MPa} / 4^{\circ} \mathrm{C}$

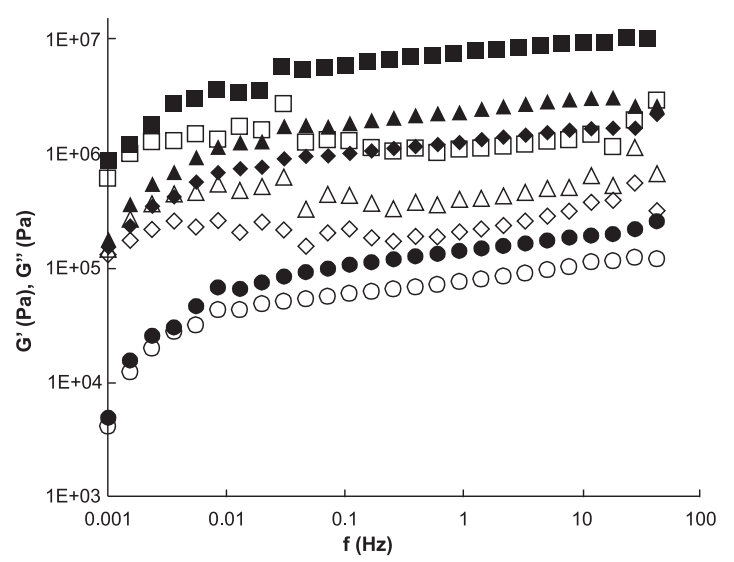

$400 \mathrm{MPa} / 20^{\circ} \mathrm{C}$ represented approximately $40 \%$ of the total aerobic mesophiles, and, in the later stages, this value increased to over $85 \%$ after $180 \mathrm{~d}$ (Fig. 7). This growth can be due to the larger tolerance of moulds and yeasts towards low $\mathrm{Aw}, \mathrm{pH}$ and moisture content.

The effect of HHP on the microbial development of pralines was assessed by measuring the total aerobic mesophiles and moulds and yeasts during storage time. A positive Pearson's correlation coefficient was observed between total aerobic mesophiles and storage time at $20{ }^{\circ} \mathrm{C}$ (Table 1) until $60 \mathrm{~d}$, including HHP $400 \mathrm{MPa} / 20^{\circ} \mathrm{C}$ and $500 \mathrm{MPa} /$ $20^{\circ} \mathrm{C}$. According to Hugas, Garriga, and Monfort (2002), this fact can be due to the ability of some microorganisms to survive HHP treatment, especially bacteria, that in presence of nutritionally rich media containing substances like carbohydrates and proteins in food emulsions (like "ganaches"), show an increased pressure resistance. After $60 \mathrm{~d}$, almost all samples presented a reduction on total aerobic mesophiles until $180 \mathrm{~d}$. The only exception was $0.1 \mathrm{MPa} / 20^{\circ} \mathrm{C}$, which can result from cracks on the chocolate couverture due to moisture migration of the filling during storage (Svanberg et al., 2012), allowing contamination from the environment. Storage at $0.1 \mathrm{MPa} / 4{ }^{\circ} \mathrm{C}$ presented the lowest contamination levels during storage and presented final values of, approximately, $2.69 \log _{10} \mathrm{cfu} / \mathrm{g}$ total aerobic mesophile.

Both HHP treatments, $400 \mathrm{MPa} / 20^{\circ} \mathrm{C}$ and $500 \mathrm{MPa} / 20^{\circ} \mathrm{C}$, were effective to better control the evolution of moulds and yeasts when compared with $0.1 \mathrm{MPa} / 20^{\circ} \mathrm{C}$ samples. The HHP treatment $500 \mathrm{MPa}$ / $20{ }^{\circ} \mathrm{C}$ presented contamination approximately $4.26 \log _{10}$ moulds and yeasts cfu/g after $180 \mathrm{~d}$, lower than $400 \mathrm{MPa} / 20{ }^{\circ} \mathrm{C}\left(5.08 \log _{10}\right.$ moulds and yeasts $\mathrm{cfu} / \mathrm{g})$ and $0.1 \mathrm{MPa} / 20{ }^{\circ} \mathrm{C}\left(5.38 \log _{10}\right.$ moulds and yeasts cfu/ g). As referred previously, the higher contamination on $0.1 \mathrm{MPa} / 20^{\circ} \mathrm{C}$

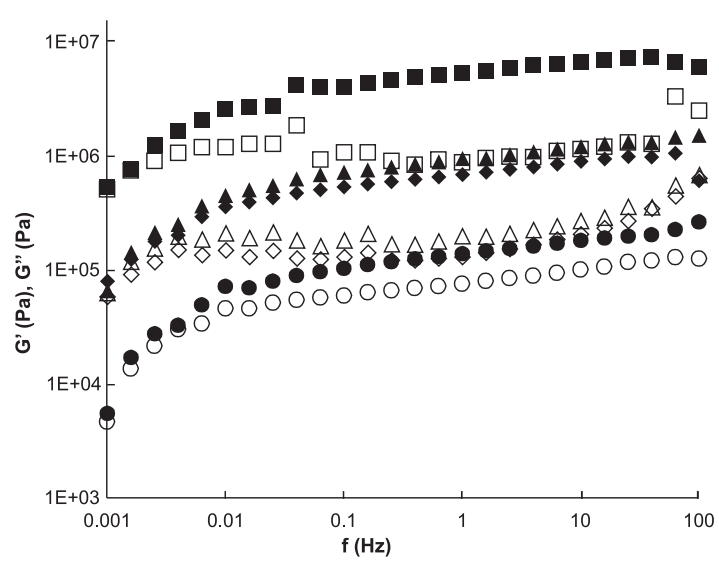

$0.1 \mathrm{MPa} / 20^{\circ} \mathrm{C}$

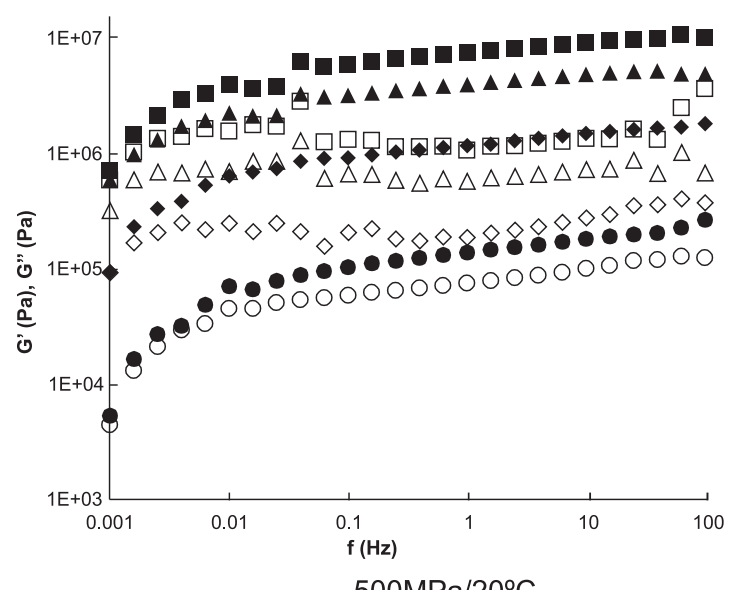

$500 \mathrm{MPa} / 20^{\circ} \mathrm{C}$

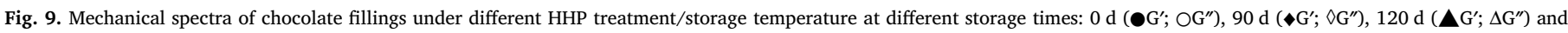
$180 \mathrm{~d}\left(\square \mathrm{G}^{\prime} ; \square \mathrm{G}^{\prime \prime}\right)$. 
can result from cracks on chocolate couverture. Storage at $0.1 \mathrm{MPa} / 4{ }^{\circ} \mathrm{C}$ presented the lowest contamination levels during storage and presented final values approximately $2.54 \log _{10}$ moulds and yeasts $\mathrm{cfu} / \mathrm{g}$.

\subsection{Rheological analysis}

The initial $\mathrm{G}_{1 \mathrm{~Hz}}^{\prime}$ value of chocolate filling was approximately $13.7 \times 10^{4} \mathrm{~Pa}$ and during storage time all tested conditions presented a positive Pearson's correlation coefficient with storage time (Table 1). After $180 \mathrm{~d}$ (Fig. 8), samples stored at $0.1 \mathrm{MPa} / 4^{\circ} \mathrm{C}$ presented the lowest storage modulus $\mathrm{G}_{1 \mathrm{~Hz}}^{\prime}\left(81.3 \times 10^{4} \mathrm{~Pa}\right)$, followed by $0.1 \mathrm{MPa}$ / $20{ }^{\circ} \mathrm{C}\left(540 \times 10^{4} \mathrm{~Pa}\right), 400 \mathrm{MPa} / 20{ }^{\circ} \mathrm{C}\left(696.6 \times 10^{4} \mathrm{~Pa}\right)$ and $500 \mathrm{MPa} /$ $20{ }^{\circ} \mathrm{C}\left(721.0 \times 10^{4} \mathrm{~Pa}\right)$.

Due to the large content of milk proteins used in the formulation of the fillings (cream and white chocolate), the higher $\mathrm{G}^{\prime}(1 \mathrm{~Hz})$ values can result from the effect of HHP on the disintegration of casein micelles into smaller casein particles (Penna et al., 2007), which aggregated protein structure and induced fat crystallization (Chawla et al., 2011). The frequency dependence of the dynamic moduli was evaluated and both storage modulus $\left(\mathrm{G}^{\prime}\right)$ and loss modulus $\left(\mathrm{G}^{\prime \prime}\right)$ are shown as mechanical spectra (Fig. 9). The results of $G^{\prime}$ and $G^{\prime \prime}$ on control sample presented a small dependency with frequency. Additionally, storage modulus ( $G^{\prime}$ ) presented higher values than loss modulus ( $\left.G^{\prime \prime}\right)$, especially from $0.01 \mathrm{~Hz}$ to $100 \mathrm{~Hz}$. These results are coherent with a gel structure. Storage time caused an increase of both storage and loss moduli during $180 \mathrm{~d}$, in all tested conditions, and no cross-over point (i.e. $\mathrm{G}^{\prime}=\mathrm{G}^{\prime \prime}$ ) was observed. As stated in the evolution of parameter $\mathrm{G}^{\prime}(1 \mathrm{~Hz})$ in Fig. 8, the mechanical spectra of $0.1 \mathrm{MPa} / 4^{\circ} \mathrm{C}$ presented a lower increase during storage time, compared with the conditions $0.1 \mathrm{MPa}$ / $20{ }^{\circ} \mathrm{C}, 400 \mathrm{MPa} / 20^{\circ} \mathrm{C}$ and $500 \mathrm{MPa} / 20^{\circ} \mathrm{C}$.

The Pearson's correlation coefficients (r) between physical-chemical properties and storage time was calculated and confirmed the influence of storage time over the properties of fillings, using $\mathrm{P}<0.05$ (Table 1).

\section{Conclusions}

According to the results presented in this work, HHP evidenced as a possible technology to improve shelf-life of filled chocolates, providing pertinent data which was missing from literature. The results obtained showed that stability of chocolate fillings during storage depended both on HHP treatment and on storage temperature. This work demonstrated that HHP treatment with pressures of about $400 \mathrm{MPa}$ during $2.5 \mathrm{~min}$, and $500 \mathrm{MPa}$ during $1 \mathrm{~min}$, influenced the microbiological stability of chocolate fillings during storage, especially moulds and yeasts, compared with non-HHP treatment and storage at $20^{\circ} \mathrm{C}$. On the other hand, the storage of filled chocolates at $4{ }^{\circ} \mathrm{C}$ presented a lower moisture loss during storage time and, as a consequence, the mechanical spectra $\left(G^{\prime}\right.$ and $\mathrm{G}^{\prime \prime}$ ) was less affected compared with storage at $20^{\circ} \mathrm{C}$. These results concluded that HHP is a suitable technology to extend shelf-life of filled chocolates, with lower energy requirements when compared with conventional refrigeration.

\section{References}

Aganovic, K., Smetana, S., Grauwet, T., Toepfl, S., Mathys, A., Van Loey, A., \& Heinz, V. (2017). Pilot scale thermal and alternative pasteurization of tomato and watermelon juice: An energy comparison and life cycle assessment. Journal of Cleaner Production, $141,514-525$.

Ali, A., Selamat, J., Che Man, Y., \& Suria, A. (2001). Effect of storage temperature on texture, polymorphic structure, bloom formation and sensory attributes of filled dark chocolate. Food Chemistry, 72(4), 491-497.

AOAC (1990). Official methods of analysis (15th ed.). Washington: Association of Official Analytical Chemists.

Aymerich, T., Picouet, P., \& Monfort, J. (2008). Decontamination technologies for meat products. Meat Science, 78, 114-129.

Beckett, S. (2008). The science of chocolate (2nd ed.). Cambridge: RSC Publishing (Chapter 10).

Briones, V., \& Aguilera, J. (2005). Image analysis of changes in surface color of chocolate. Food Research International, 38, 87-94.
Briones, V., Aguilera, J., \& Brown, C. (2006). Effect of surface topography on color and gloss of chocolate samples. Journal of Food Engineering, 77(4), 776-783.

Chawla, R., Patil, G., \& Singh, A. (2011). High hydrostatic pressure technology in dairy processing: A review. Journal of Food Science and Technology, 48(3), 260-268.

Clariana, M., Guerrero, L., Sárraga, C., Díaz, I., Valero, A., \& García-Regueiro, J. (2011). Influence of high pressure application on the nutritional, sensory and microbiological characteristics of sliced skin vacuum packed dry-cured ham. Effects along the storage period. Innovative Food Science \& Emerging Technologies, 12, 456-465.

Curley, W. (2011). Couture chocolate. London: Jacqui Small.

Dahlenborg, H., Millqvist-Fureby, A., \& Bergenståh, B. (2015). Effect of particle size in chocolate shell on oil migration and fat bloom development. Journal of Food Engineering, 146, 172-181.

De Clercq, N., Van Coillie, E., Van Pamel, E., De Meulenaer, B., Devlieghere, F., \& Vlaemynck, G. (2015). Detection and identification of xerophilic fungi in Belgian chocolate confectionery factories. Food Microbiology, 46, 322-328.

Denoya, G., Polenta, G., Apóstolo, N., Budde, C., Sancho, A., \& Vaudagna, S. (2016). Optimization of high hydrostatic pressure processing for the preservation of minimally processed peach pieces. Innovative Food Science \& Emerging Technologies, 33, 84-93.

Dias, J., Almeida, M., Adikevičius, D., Andzevičius, P., \& Alvarenga, N. (2016). Impact of olive oil usage on physical properties of chocolate fillings. Grasas y Aceites, 67(3), e145.

Dias, J., Alvarenga, N., \& Sousa, I. (2015). Effect of hydrocolloids on low-fat chocolate fillings. Journal of Food Science and Technology, 52(11), 7209-7217.

Diez, A., Santos, E., Jaime, I., \& Rovira, J. (2008). Application of organic acid salts and high-pressure treatments to improve the preservation of blood sausage. Food Microbiology, 25, 154-161.

Ghosh, V., Ziegler, G., \& Anantheswaran, R. (2002). Fat, moisture and ethanol migration through chocolates and confectionery coatings. Critical Reviews in Food Science and Nutrition, 42(6), 583-626.

Hernández-Carrión, M., Hernando, I., Sotelo-Díaz, I., Quintanilla-Carvajal, M., \& Quiles, A. (2015). Use of image analysis to evaluate the effect of high hydrostatic pressure and pasteurization as preservation treatments on the microstructure of red sweet pepper. Innovative Food Science \& Emerging Technologies, 27, 69-78.

Hugas, M., Garriga, M., \& Monfort, J. (2002). New mild technologies in meat processing: High pressure as a model technology. Meat Science, 62, 359-371.

IFST (1993). Shelf-life of foods: Guidelines for its determination and prediction. London: Institute of Food Science and Technology.

Janowicz, M., \& Lenart, A. (2015). Selected physical properties of convection dried apples after HHP treatment. LWT, 63, 828-836.

Jinap, S., Ali, A., Che Man, Y., \& Suria, A. (2000). Use of palm mid-fraction in dark chocolate as base filling centre at different storage temperatures. International Journal of Food Sciences and Nutrition, 51, 489-499.

Landl, A., Abadias, M., Sárraga, C., Viñas, I., \& Picouet, P. (2010). Effect of high pressure processing on the quality of acidified Granny Smith apple purée product. Innovative Food Science \& Emerging Technologies, 11, 557-564.

Marvig, C., Kristiansen, R., Madsen, M., \& Nielsen, D. (2014). Identification and characterisation of organisms associated with chocolate pralines and sugar syrups used for their production. International Journal of Food Microbiology, 185, 167-176.

Miquelim, J., Alcantara, M., \& Lannes, S. (2011). Stability of fruit bases and chocolate fillings. Ciência e Tecnologia de Alimentos, 31(1), 270-276.

Mota, M., Lopes, R., Delgadillo, I., \& Saraiva, J. (2015). Probiotic yogurt production under high pressure and the possible use of pressure as an on/off switch to stop/start fermentation. Process Biochemistry, 50, 906-911.

Nightingale, L., Lee, S., \& Engeseth, N. (2011). Impact of storage on dark chocolate Texture and polymorphic changes. Journal of Food Science, 76(1), c142-c153.

Nopens, I., Foubert, I., De Graef, V., Van Laere, D., Dewettinck, K., \& Vanrolleghem, P. (2008). Automated image analysis tool for migration fat bloom evaluation of chocolate coated food products. LWT, 41, 1884-1891.

Penna, A., Subbarao-Gurram, \& Barbosa-Cánovas, G. (2007). High hydrostatic pressure processing on microstructure of probiotic low-fat yogurt. Food Research International, 40, 510-519.

Popov-Raljić, J., \& Laličić-Petronijević, J. (2009). Sensory properties and color measurements of dietary chocolates with different compositions during storage for up to 360 days. Sensors, 9, 1996-2016.

Pradas, I., del Pino, B., Peña, F., Ortiz, V., Moreno-Rojas, J., Fernández-Hernández, A., \& García-Mesa, J. (2012). The use of high hydrostatic pressure (HHP) treatments for table olives preservation. Innovative Food Science \& Emerging Technologies, 13, 64-68.

Santos, M., Nunes, C., Jourdes, M., Teissedre, P., Rodrigues, A., Amado, O., ... Coimbra, M. (2016). Evaluation of the potential of high pressure technology as an enological practice for red wines. Innovative Food Science \& Emerging Technologies, 33, 76-83.

Subramaniam, P. (2009). 12-Shelf-life prediction and testing. In G. Talbot (Ed.). Science and technology of enrobed and filled chocolate, confectionery and bakery products (pp. 233-254). Oxford: Woodhead Publishing Limited.

Svanberg, L., Lorén, N., \& Ahrné, L. (2012). Chocolate swelling during storage caused by fat or moisture migration. Journal of Food Science, 77(11), E328-E334.

Vázquez, M., Torres, J., Gallardo, J., Saraiva, J., \& Aubourg, S. (2013). Lipid hydrolysis and oxidation development in frozen mackerel (Scomber scombrus): Effect of a high hydrostatic pressure pre-treatment. Innovative Food Science \& Emerging Technologies, 18, 24-30.

Vercet, A. (2003). Browning of white chocolate during storage. Food Chemistry, 81, 371-377.

Wybauw, J. (2004). Fine chocolates great experience. Tielt: Uitgeverij Lannoo nv.

Wybauw, J. (2010). Fine chocolates great experience 3 - Extending shelf life. Tielt: Uitgeverij Lannoo nv. 